Renata Podgórzańska ${ }^{1}$

\title{
REGIONAL COOPERATION IN THE PROCESS OF INTEGRATION OF THE WESTERN BALKAN STATES WITH THE EUROPEAN UNION
}

Keywords: European integration, regional cooperation, European Union, Western Balkans

\begin{abstract}
From the European Union perspective regional cooperation in the Western Balkans is one of the fundamental conditions determining the pace of accession to European structures. This question is emphasized in EU documents concerning the enlargement, and it is also each time a subject of the EU's discussion with representatives of Western Balkan countries. The aim of this paper is to articulate and characterize the premises of EU activity towards Western Balkans and to analyze forms of regional cooperation with the participation of Western Balkan countries as well as an exegesis of factors determining this cooperation.
\end{abstract}

\section{INTRODUCTION}

Integration of the Western Balkan countries with the European Union is determined by a number of factors of a diversified nature. The pace and nature of the process of approximation with European cooperation structures is determined by multiple and mutually conditioning phenomena. What is more, they are located both on the side of the aspirant countries, as well as in the EU's

1 Renata Podgórzańska, University of Szczecin, Faculty of Humanities, Institute of Political Science and European Studies, renata.podgorzanska@wp.pl. ORCID ID: 0000-0001-6610-9699 
capabilities and possibilities to incorporate further countries, its potential and action strategy. Taking into account the specifics of states located in the area of the Western Balkans, their nature, historical experience, current activity for accession, the EU is monitoring the process of implementing membership requirements. Therefore, it suggests intensifying activity in fields where there are significant departures from norms and values perceived by it as fundamental. To this end, i.a. it encourages the Balkan states to intensify regional cooperation seeing it not only as one of the fundamental mechanisms supporting the process of integration with the EU, but most of all reinforcing the process of political, social and economic stabilization of the region. The EU's position is based on an assumption that tightening cooperation between the Balkan states is particularly important in strengthening security in the region. Taking into account the recent past, associated with the break-up of former Yugoslavia and related events, the EU is searching for ways to strengthen stability in the region which not so long ago was an arena for a gory armed conflict.

Reality in the Western Balkan countries (those outside the EU structures) is still far from desirable. Multiethnicity and multinationalism are still a source of crises, thus threatening the region's security as much as the security of the EU (Podgórzańska, 2015, pp. 129-132). Regardless of the specificity of individual countries, the identical nature of political, economic and social problems, historical experience and, above all, the targets that the EU wants to achieve have prejudged making the Western Balkans subject to EU support. From the Union's perspective, regional cooperation is a preliminary, but one of the vital conditions for joining European structures. This is why this issue is emphasized in EU documents concerning the enlargement and is also each time a subject of the EU's discussion with representatives of the Western Balkan countries. Excluding Albania, the paper restricts the analysis to the countries that were formed as a result of the break-up of the Socialist Federal Republic of Yugoslavia, that is: Bosnia and Herzegovina, FYROM, Montenegro, Serbia and Kosovo. They are countries belonging to the region geographically, aspiring to EU membership and included in the enlargement policy. 


\section{TERMINOLOGY APPARATUS}

It is necessary to clarify the category of "Western Balkans" for the needs of this discussion. This term became popular after negotiating a peace agreement in 1995 in Dayton and signing it in Paris as a term referring to the area particularly affected by the outcomes of conflicts in the Balkans in the 1990s. It was first used in 1998 during the Council of Europe summit in Vienna and was permanently inscribed in the EU's term network (Bujwid-Kurek, 2011, p. 254). The EU uses it thus defining the sub-region including Albania, Bosnia and Herzegovina, Croatia, Former Yugoslav Republic of Macedonia (FYROM), Montenegro, Serbia and Kosovo. It is worth noting that this term become popular along with the crystallization of the EU's policy towards countries established as a result of the disintegration of former Yugoslavia.

Common elements that allow separating this sub-region include geographical location, common tradition of statehood within SFRY, experience related to the disintegration of former Yugoslavia and accompanying military action, the need for modernization, transformation and democratization or similar goals in foreign policy, mainly in reference to Euro-Atlantic aspirations. The factor binding the sub-region is the presence and involvement of the international community for stabilization in the post-conflict area and perceiving it collectively by the international community. Taking into account the experience to date, it needs to be stressed that the international community is the factor that stimulates and forces the creation of certain political, social and economic bonds, also those fostering regional cooperation. The community, the convergence of interests and the need for joint action are the attributes stressed by the EU as necessary for the development of various forms of cooperation in the region, at the same time serving the process of approximation with the EU structures (Podgórzańska, 2015, pp. 129-132).

The process of developing various forms of regional cooperation, from casual initiatives to more formalized forms sanctioned by signing appropriate legally binding agreements, is developing in Europe alongside integrational processes. It is a reflection of countries' searching for effective forms of joint action, which are to result in the development of states that this joint action concerns. Developing regional cooperation by default is supposed to serve all 
actors participating in it, taking into account their needs, expectations and interests. The community of needs and interests ignites actions related to the search for ways to intensify cooperation. The latter may have a more or less formalized nature. The fundaments of regional cooperation include neighbourhood, geographical location, the community of experience, sometimes similar economic or social problems, the desire to overcome common threats, breaking historical prejudices, joint pursuit of assumed targets (Podgórzańska, 2006, pp. 158-159). This kind of cooperation between states requires taking into account different attitudes and the need to seek agreement on matters that are, or may be, the subject of joint action. Many premises support the development of regional cooperation. Most of all joint action in matters that are of interest to all participants enhances the chances of reaching the assumed goals and the achievement of common intentions. This community and co-dependence of interests is the factor that encourages cooperation.

In most cases, regional cooperation taking the form of casual, informal groupings aims to improve relations in the region, overcome past prejudices or resentments and to build new connections in many areas of political, economic, cultural and social life. The emerging new associations group countries with similar interests and countries that in their action are guided by a similar system of values. These structures generally carry out three groups of tasks: exchanging information on current issues and conducting political consultations, sectorial cooperation in the sub-regions as well as joint initiatives and addressing international organizations (Gajewski, 2002, p. 297). For the sake of completion, it should be emphasized that the basis for regional cooperation is the closeness of cooperating states, their identical character and interactions taking place. The group of countries constituting the foundation of cooperation in the region is distinguished not only due to its geographic proximity, but economic, political, cultural, defense, etc. ties also play an important role in stimulating joint action and the community of interests.

\section{GOALS OF THE EU'S POLICY TOWARDS THE WESTERN BALKANS}

In view of the complex past of the Western Balkans, and most of all taking into account the existence of various factors determining the situation in this part 
of Europe, the EU has for years been searching for ways to strengthen stability. By encouraging the Balkan countries to cooperate and by aiding them in this regard through offering different kinds of support mechanisms it strives for permanent reinforcement of peace and security seeing these values as fundamental from the point of view of the region's development. It needs to be stressed here that the strategy and nature of EU policy towards the Western Balkans has evolved over the years (Olszewski, 2010, pp. 180-195). What is more, it needs to be highlighted that EU activity towards this region was dictated by the development of events on the area of former Yugoslavia and it was them that decided about the instruments and intensity of EU support for the region (Molendowski, 2011; Szpala, 2017). It needs to be noted that the EU has focused its activity for a longer while predominantly on actions for the security of the region, getting involved in and initiating actions serving to rebuild and stabilize the region. Due to the lack of clearly formulated prospect of accession of the Western Balkan countries to the EU, the scope, nature and pace of transformation of the Balkan reality was hugely unsatisfactory. With time, by concretizing the offer of support for the countries of the region and, most importantly, by formulating the prospect of accession for countries that meet the required criteria, it has had an activating effect on the region. What is worth emphasizing, the institutionalization of cooperation with the EU and most of all the prospects of accession offered to the countries of this region are seen as a factor reinforcing peace and security in the entire region.

The UE, in search for ways to actuate the transformation processes in the Balkan countries, concluded that the success of all offered actions will be determined by the level and nature of cooperation in the region. The barriers still present in the Balkan reality that take the form of unresolved disputed issues or long-standing antagonisms have negatively affected the security in the region. It was then concluded that regional cooperation seen as a key factor supporting rebuilding ties and friendly, good neighbourly relations between the Balkan countries will be one of the vital requirements for accession (Communication from the Commission to the European Parliament, the Council, the European Economic and Social Committee and the Committee of Regions. Enlargement Strategy and Main Challenges 2014-15). Combining the issue of regional stabilization with the issue of preparing individual countries for EU membership was shown after the end of hostilities in the area of former Yugoslavia. However, 
it needs to be noted that initially the possibility of gaining EU membership by the countries established as a result of the disintegration of former Yugoslavia was not pointed out directly. Setting aside the deeper analysis of the EU's policy towards the region of the Western Balkans, one needs to highlight the systematic concretization of the EU offer for the countries of this region, which was supposed to foster reinforcing security and stabilization by approximation with, and in the perspective accession to, its structures. What is important, the EU's policy for the region was modified under the influence of the development of events in the region and one also needs to note here that it was the ineffectiveness of the solutions offered initially (e.g. the so-called regional approach suggested in February 1996) that forced a verification of the EU policy, contributing at the same time to the development of more effective tools serving the Western Balkans' approximation with the EU in the form of the Stabilisation and Association Process. It was to be a new framework for the development of relations between the EU and the Western Balkan countries, and what it most important, it was supposed to offer a reliable membership prospect. At the EU summit in Thessaloniki in 2003 it was concluded that in order to accelerate the reform process and lasting stability, it is necessary to ensure the prospect of EU membership for all Balkan countries after meeting the relevant criteria and adopting EU regulations (Nowak-Far, 2012, pp. 60-72). Taking into account the recent war past of the region, the requirements of regional cooperation, reconciliation and dispute resolution were added to the so-called Copenhagen Criteria (Szpala, 2017). Regional cooperation has thus become a key category from the point of view of the process of approximation with the EU (Paszkiewicz, 2013, p. 517). Its scope, character and dynamics became the point of assessment of the progress recorded by individual Western Balkan countries. At the same time, the criteria for assessing the progress in the process of approximation with the EU include a far wider catalogue of requirements, while regional cooperation is only one of the elements subject to assessment.

The experience of the recent dozen years show the need of consistent support for the countries of the region in their action for cooperation with the European structures. The successes of countries such as Croatia show that determination, involvement and the will to meet the necessary requirements, with the support from EU institutions, are a guarantee of success of the undertaken activity. At the same time Croatia was the only Western Balkan country (apart 
from Slovenia) that met the accession requirements and was included in the EU structures. As a consequence, the specific regression in the enlargement process, determined by complex political and economic factors, required the EU to verify its approach and most of all to specify the aims of its own activity towards the region. The EU's limited activity towards the Western Balkans noticeable since 2008 has resulted in the lowering of the transformation dynamics of the countries of the region. Aforementioned Croatia was the country that consistently met the EU requirements with hope for EU activation. The remaining countries featured a different pace of changes. Paradoxically, as Marta Szpala notes, it was beneficial from the point of view of the EU itself, absorbed in its own problems and unable to continue its active enlargement policy. The insufficient level of meeting the accession requirements by the Balkan states allowed the postponement of challenges related to the admission of new members (Szpala, 2018). At the same time, the problem was not only in the absence of decisive actions on the part of the aspirant countries or insufficient, in the EU's opinion, fulfillment of the formulated requirements. The lowering of the level of motivation resulted partly from the lack of a clear, consistent policy on the part of the EU, which, depending on the development of the situation in the region and emerging problems, modified its expectations (Szpala, 2018). What is more, the 2014 announcement of Jean-Claude Juncker who stated that in the next five years there will be no new enlargement, weakened the modernization impetus in the Balkan states. Juncker's stating that "the EU needs to take a break from enlargement so that we can consolidate what has been achieved among the 28 ", postponing the potential accession, weakened - what needs to be stressed - the readiness to introduce the necessary changes (Questions and Answers: The Juncker Commission)

The migration crisis was the driving force behind the EU's policy towards the Western Balkans. The current stagnation and lack of enlargement prospects due to the importance of the Western Balkans in managing migration has made the EU's activity towards the region more dynamic, part of which was the enlargement policy (Podgórzańska, 2017, pp. 305-308). On a side, it is worth noting that the region's geopolitical role and activation of various actors such as Russia, Turkey or China, were, alongside the migration crisis, the driving force behind the EU's policy towards the region (Bukowski, 2018, pp. 95-96; Olszewski, Chojna, 2017, pp. 140-144; Szpala, 2018). The enlargement of the 
list of actors competing for influence in the region made the EU's activity more dynamic, who tried to maintain the dominant position in the region. Most of all, though, the search for effective instruments of managing migration flows that would allow the EU to effectively counteract the negative consequences of the migration crisis, caused renewed appreciation of the region. Seeing the importance of the Western Balkans as key from the perspective of the migration crisis verified the EU's current policy and new solutions were offered (Szymańska, 2017, pp. 164-180).

The experience to date confirms the thesis that only the prospect of the region's accession to the $\mathrm{EU}$ is an impulse and motivation to continue the region's transformation processes. Clearly defined expectations towards the countries of the region, at the same time with the support for their actions, was a specific incentive and, what is crucial, could strengthen Balkan societies' integration attitudes. It should be noted that the time that has passed since the last enlargement (2013) from the EU perspective was characterized by a significant dynamism of events modeling the European policy. Subsequent crises caused a decrease in the activity for enlargement. Focusing efforts towards internal consolidation of the EU and, above all, limiting the negative consequences of either the debt crisis of the euro area, or the migration crisis and Brexit, marginalized the problem of the accession of the Western Balkans (Podgórzańska, 2013, pp. 98-99).

Emphasizing the importance of the accession of the Balkan countries for the security and stability of the region, the EU actuates its own activity for enlargement by a strategy adopted in February 2008 for a credible enlargement perspective for and enhanced EU engagement with the Western Balkans (Communication from the Commission to the European Parliament, the Council, the European Economic and Social Committee and the Committee of the Regions). Both the document referred to and the medium-term strategy adopted by the European Commission in November 2015 on the EU enlargement policy, formulating expectations for the Balkan countries, at the same time point out targets that can be achieved (Communication from the Commission to the European Parliament, the Council, the European Economic and Social Committee and the Committee of the Regions. EU Enlargement Strategy). From the EU perspective, the extension of the sphere of influence of European values to the Western Balkans is the basic premise of activity strengthening security and serving both 
the development of the EU as a whole and individual Member States, including the Western Balkan countries. Confirmation of the European perspective of the region took place during the EU-Western Balkans summit in Sofia on 17 May 2018. Taking a decision to support political, economic and social changes in this region, the $\mathrm{EU}$ wants to strengthen the accession efforts of the Balkan states and bind them more strongly (in view of the activity of other countries in the region) with the family of European countries. It needs to be stressed that the EU confirmed the importance it assigns to the cooperation between the Western Balkan countries, which through the development and implementation of definitive, inclusive and binding solutions for bilateral disputes between partners, rooted in the legacy of the past and devoting additional efforts to reconciliation will serve the stability of the region (Sofia Declaration, 17 May 2018). It was concluded that constructing a web of connections in the region is vital for bringing societies and economies of the Western Balkan countries closer together, and thus will serve to enhance political stability, economic prosperity, cultural and social development.

It needs to be remembered here that the $\mathrm{EU}$ formulates identical requirements towards the Western Balkan countries. At the same time, individual countries differ in their level of advancement of cooperation with EU institutions, where it was determined by complex social, political and economic conditions. One of the significant premises of the verification of progress is the assessment of the nature and intensity of regional cooperation and good neighbourly relations. From the EU's perspective these conditions are indispensable for individual countries to achieve progress on their way to European integration. Good neighbourly relations and regional cooperation are two basic elements of the process of stabilization and association and the enlargement process. Encouraging them to maintain regular inter-governmental contact, bilateral cooperation and cooperation at the regional level, the EU wants to integrate the Western Balkan countries strongly (Communication from the Commission to the European Parliament, the Council, the European Economic and Social Committee and the Committee of the Regions. 2018 Communication on EU Enlargement Policy). From the point of view of stability in the region, cooperation between the Balkan countries and strengthening ties between them is a fundamental requirement of progress in terms of accession. Regional cooperation is therefore vital to ensure the region's political stability and economic 
opportunities, which was expressed in the aforementioned declaration of the EU-Balkans summit in May 2018.

The EU encourages active participation in regional initiatives seeing this form of cooperation of the Western Balkan countries as essentially strengthening their European prospect. From its perspective, it is to serve stability in the region, reconciliation, overcoming the legacy of the past and solving problems in bilateral relations. It is commonly assumed that the institutionalization of regional international relations in the region fosters the development of economic, social and political cooperation and contributes to comprehensive progress of civilization.

\section{FORMS OF REGIONAL COOPERATION WITH THE PARTICIPATION OF THE WESTERN BALKAN COUNTRIES}

In view of the factors that determined the outbreak of the armed conflict in the Balkans in the 1990s, the countries located in this region are being encouraged to look for various formulas of multilateral cooperation. At the same time it is worth noting that due to still vivid resentment in the region, it was for years difficult to talk about lasting forms of cooperation between the countries. Despite the efforts of the international community, as well as the activity of the Balkan states themselves, the occurring factors destabilizing the situation in the region (for example territorial disputes) make it difficult to launch regional cooperation mechanisms. Notwithstanding the above restrictions, in the second half of the 1990 s, attempts to intensify regional cooperation gradually began to appear seen as a necessary condition to improve neighbourly relations and as a result of political and economic stabilization. Although the actions for years have been and still are marked by the historical legacy that hinders integration activities, efforts have been consistently made to strengthen cooperation in the regional dimension (Olszewski, 2011, p. 312). The European Union, as the main actor in the process of stabilization in the Balkans, mobilizes the Balkan states to ensure that regional cooperation and good neighbourly relations are an essential part of their policy. Recognizing that they contribute to stability, reconciliation and climate that fosters solving open bilateral issues and the legacy of the past, they entice by offering various types of support, both organizational and financial. 
As noted by Paweł Olszewski, despite negative aspects resulting from the interests of individual Balkan countries and differences in perceiving the region's role and significance in Europe and the world, Balkan states do see the need and necessity to increase cooperation (Olszewski, 2011, p. 313). Regional cooperation is advocated for not only by the desire to strengthen modernization processes but also Euro-Atlantic aspirations of the Balkan countries. At the same time it needs to be emphasized that cooperation in the region was and still is a requirement formulated by the EU. Incidentally, it needs to be noted that the lack of substantial progress in building regional structures including in their scope countries that arose on the rubble of former Yugoslavia was determined by the fact that these initiatives were in a specified way enforced by the international community (Paszkiewicz, 2013, p. 518). Western countries, striving to create lasting political and economic structures that are to integrate the region, enforced a specified philosophy of action with which the Western Balkan countries gradually identified. Historical experience and recent memory of the events of the 1990s related to the disintegration of former Yugoslavia at the beginning caused reluctance and lack of trust. However, systematically, along with EU pressure, these countries have been mobilizing to increase their activity for undertaking various regional initiatives.

In the process of concretizing forms of regional cooperation in the Western Balkans, the attention is drawn by the presence of many initiatives of a different nature and range. However, above all, the EU was primarily the motivation for undertaking various initiatives. From the beginning of its involvement in the Balkans, the question of cooperation in the region was perceived by it as a necessary requirement, conducive to security and stabilization. Various forms of cooperation were postulated, which included both the countries of the region and third countries as well as international organizations, financial institutions and other actors involved in activities for the security in the Western Balkans. The idea of including the Balkan countries in international mechanisms serving to rebuild the region was reflected in the Stability Pact for South Eastern Europe (Sokołowska, 2007, pp. 207-210). It obliged the Western Balkan states to establish and actively develop regional cooperation, perceived as a necessary condition strengthening stability and security in the post-conflict area of former Yugoslavia (Olchowski, Pawłowski, 2009, p. 83). This broad formula of the Pact's participants (since 2007 the Regional Cooperation Council) was an expression 
of involvement of the international community in the process of integration of the Western Balkans with the international community, and its primary goal was lasting establishment of peace and security (Olchowski, Pawłowski, 2009, p. 83).

Other forms of multilateral cooperation in which the Western Balkans participated, important from the point of view of the region's development, were, among others: CEFTA (Central European Free Trade Agreement), established in 1992, renewed in 2006, that is an agreement on the establishment of a regional free trade zone that brings together 9 countries of South East Europe; the Central European Initiative, established in 1989, which is supposed to support the process of adapting, among others, the Western Balkan states to EU standards and ultimately foster the process of their integration with EU structures; the South-East Europe Cooperation Process, functioning since 1996, which is an important example of the Balkan states' own, independent activity; the Southeast European Cooperative Initiative, launched in 1996, founded as a forum for political consultations between the countries of the region in order to ensure its political and economic stabilization; the Adriatic and Ionian Initiative of 2000; the Danube Cooperation Process initiated in 2002 (Olechowski, Pawłowski, 2009 , pp. 83-87). The following forms of cooperation are equally important from the point of view of stabilization in the region, and most of all approximation with EU institutions: Western Balkans Six, one of whose main aims is building and connecting transport and energy infrastructure as a driver for growth and jobs (Western Balkans...). RECOM plays an extremely important role - the official, intergovernmental commission established jointly by states formed as a result of the break-up of the former SFRY. The task of RECOM is to establish facts regarding all war crimes and other serious human rights violations related to the war (What Is RECOM?). It is worth mentioning the Regional Initiative for Migration and Asylum here, an initiative that forms part of the cooperation process in the South-East Europe, whose aim is to strengthen regional cooperation in terms of migration by promoting comprehensive, integrated and coherent approach to the issues of migration, asylum, border management, visa policy and consular cooperation and return of refugees ( $\mathrm{Mi}$ gration, Asylum, Refuges Regional Initiative). The Brdo-Brijuni initiative has an interesting nature. The aim of establishing this informal regional initiative was to strengthen ties in the Western Balkans region so that the reinforced cooperation would aid quicker progress on their path to European integration. The 
Process of Brdo-Brijuni was launched in 2013 on the initiative of Slovenia and Croatia in order to further stabilize conditions in South-East Europe through regional cooperation and solving open problems (What is the Process of BrdoBrijuni and what is the Significance for BiH?).

The involvement of Western Balkan states in the above-mentioned formats, as well as their participation in other forms of regional cooperation, of a more or less institutionalized and formalized nature (Treaty establishing the Energy Community, Treaty establishing Transport Community, the European Common Aviation Area) indicates their readiness to meet membership requirements. It ought to be remembered that regional cooperation is assessed each time and is reflected in the European Commission's communications on the progress of EU aspirants in the context of meeting the formulated requirements. However, the most important goal of cooperation is to strengthen stability in the region, to foster reconciliation and to build a climate conducive to solving open bilateral issues and the legacy of the past.

Formats functioning for years have featured a varied level of formalization and thus effectiveness. Despite the occurrence of a number of initiatives and forms, the institutionalization of regional cooperation remains limited and effects of cooperation are far from expected (Olechowski, Pawłowski, 2009, p. 87). The initiatives arranged to a large extent by the international community, primarily the EU, in sectors such as transport, energy, social issues, security, including combating organized crime, police cooperation, border protection, did not always bring expected results. Nevertheless, without a doubt, they were the motivation for Western Balkan countries to search for such areas in which all actors of cooperation saw benefits of regional integration. Despite the noticed mistrust, lack of political willingness for broader cooperation in the region and mutual suspicion, international pressure was a sufficient premise to take action in areas in which these countries saw - as noticed above - political or economic benefits. The experience of recent years in the context of regional cooperation, perceived barriers and limitations also motivate to seek new formulas for the cooperation of countries located in South East Europe. The example is a new format of regional cooperation, the so-called Four of Varna. Its establishment entails recognition of previous formats of cooperation focused on Western Balkans as insufficiently adapted to the needs of the remaining countries of South East Europe. Due to the fact that next to Bulgaria, Greece and Romania the 
cooperation also includes Serbia, this format is vital in the context of including the Western Balkan states in the orbit of regional cooperation.

The Balkan states are still being encouraged to both join in the existing formats of cooperation, of a various nature, a different level of institutionalization and a varied number of actors participating in it, and to initiate new ones. The cooperation participants include both the Western Balkan countries aspiring to EU membership and the remaining countries of South East Europe that have the status of Member States. At the same time it is worth noting that regardless of the nature of this cooperation, motives associated with its initiation, the aims served by strengthening ties in the region are essential. This activity is most of all focused on reinforcing security and stabilization in the region, economic stabilization of the countries of the region after the period of armed conflicts and help in integration with the EU. Achieving the desired state is possible by taking the initiative in such areas as: economy, energy, transport, infrastructure, ecology, culture, research. Due to the migration crisis and its repercussions for the EU's enlargement policy the vital areas of cooperation include the issues of migration, border protection and fighting organized crime. Also issues such as the prosecution of war crimes, the regulation of border disputes and the regulation of the status of national ethnic minorities are still possible as a result of undertaking various forms of regional cooperation.

The value of cooperation platforms for political and economic stability of the region depends on a number of various factors. The nature of the format of regional cooperation, the number of cooperating countries and their status (aspirant countries or EU Member States) play a vital role. Regardless of whether we are dealing with a cooperation platform such as the South-East European Cooperation Process or the Regional Cooperation Council gathering a dozen or more countries or formats associating a smaller number of countries, it is important that they pursue aims fostering political and economic stabilization of the region (Pieńkowski, Żornaczuk, 2018).

\section{CONCLUSION}

The cooperation of the Western Balkan sates, expected and required by the EU as the basic condition serving the region's integration with the structures of 
European cooperation is an essential premise motivating the countries in the region to undertake various forms of cooperation. At the same time, however, external pressure means that this cooperation lacks political willingness on the part of the Western Balkan states to intensify ties. Historical experience and national and ethnic reminiscences still present in the Balkan reality mean that the desired reconciliation and building truly good neighbourly relations are still miles away. Regional cooperation carried out as a response to the EU's expectations has not brought the expected outcome in the form of close regional integration. The EU is still the driving force, an actor encouraging and supporting all initiatives. The example here is the promoted idea of creating the Regional Economic Area. The EU and the European Bank for Reconstruction and Development are the advocates for closer economic cooperation (Factsheet: EU Engagement in the Western Balkans). Despite the functioning of many initiatives, with varying degrees of institutionalization and concretization, of various scope and character, from international fora to bottom-up initiatives (Paszkiewicz, 2013, p. 526), regional integration is far away. The presence and activity of the EU and the accession efforts of individual countries in the region are still a guarantee of developing various forms of international cooperation in the region. In many cases the EU is the actor that strengthens cooperation in the region and encourages deepening correlations between the Balkan countries. The Regional Economic Area is an example promoted by it (and by the European Bank for Reconstruction and Development), which would foster the creation of a common market in this region (Kośka, 2017). The skepticism of some Balkan countries concerning this idea makes us aware of the current particularism and the lack of a sense of shared responsibility for development, stabilization and security in the region.

\section{BIBLIOGRAPHY:}

Bujwid-Kurek, E. (2011). Populizm w państwach Bałkanów Zachodnich. Krakowskie Studia Międzynarodowe, 4, pp. 255-266.

Bukowski, P. (2018). Geopolityczne źródła potencjalnych konfliktów w zachodniej części Bałkanów. Przegląd Geopolityczny, 24, pp. 87-100.

Communication from the Commission to the European Parliament, the Council, the European Economic and Social Committee and the Committee of Re- 
gions. Enlargement Strategy and Main Challenges 2014-15. Downloaded from: https://bit.ly/2FuYaUq.

Communication from the Commission to the European Parliament, the Council, the European Economic and Social Committee and the Committee of the Regions. A credible enlargement perspective for and enhanced EU engagement with the Western Balkans. Downloaded from: https://bit.ly/2FncJd9.

Communication from the Commission to the European Parliament, the Council, the European Economic and Social Committee and the Committee of the Regions. EU Enlargement Strategy. Downloaded from: https://bit.ly/2RJIyTk.

Communication from the Commission to the European Parliament, the Council, the European Economic and Social Committee and the Committee of the Regions. 2018 Communication on EU Enlargement Policy. Downloaded from: https://bit.ly/2DbPfr9.

Deklaracja z Sofii, 17 maja 2018 r. Downloaded from: https://www.consilium.europa.eu/media/34797/sofia-declaration_pl.pdf.

Factsheet: EU Engagement in the Western Balkans. Downloaded from: https://bit. ly/2GZGZbc.

Gajewski, J. (2002). Europa Środkowa w polskiej polityce zagranicznej. In. R. Kuźniar, K. Szczepanik (eds.). Polityka zagraniczna RP 1989-2002 (pp. 276-313). Warszawa: Wydawnictwo Askon.

Kośka, M. (2017). Unia promuje Regionalny Obszar Gospodarczy na Bałkanach. Downloaded from: https://bit.ly/2FqC997.

Lasoń, M. (2015). Polityczne wyzwania integracji europejskiej - ewolucja UE. In: E. Cziomer (ed.), Współczesne stosunki międzynarodowe. Międzynarodowe stosunki polityczne w XXI wieku - geneza, struktury, funkcje i procesy polityczne (pp. 96-133). Kraków: Oficyna Wydawnicza AFM.

Migration, Asylum, Refuges Regional Initiative (MARRI). Downloaded from: https://bit.ly/2sqBYmg

Molendowski, E. (2011). Kraje Bałkanów Zachodnich - główne problemy współpracy i integracji z krajami Unii Europejskiej. Zeszyty Naukowe Uniwersytet Ekonomiczny w Poznaniu, 179, pp. 210-223.

Nowak-Far, A. (2012), Bałkany Zachodnie a Unia Europejska - prawidłowości procesu integracji. In. A. Nowak-Far (ed.), Integracja Bałkanów Zachodnich z Unia Europejska (pp. 41-87). Warszawa: Wydawnictwo Poltext.

Olchowski, P., Pawłowski, K. (2009). Europa Południowo - Wschodnia. In: I. Topolski, H. Dumała, A. Dumała (eds.). Regiony w stosunkach międzynarodowych (pp. 73-100). Lublin: Wydawnictwo Uniwersytetu Marii Curie-Skłodowskiej.

Olszewski, P. (2011). Współpraca regionalna na Bałkanach po 1989 roku. Studia Polityczne, 27, pp. 305-322. 
Olszewski, P., Chojna, A. (2017). Rywalizacja Unii Europejskiej i Rosji na obszarze Bałkanów Zachodnich. Rocznik Integracji Europejskiej, 11, pp. 135-146.

Olszewski, P. Bałkany Zachodnie w polityce Unii Europejskiej. Downloaded from: https://bit.ly/2RPhzWI.

Paszkiewicz, J. (2013). Współpraca regionalna na Bałkanach Zachodnich z perspektywy Unii Europejskiej. Przesłanki i przeszkody. In. P. Chmielewski, S.L. Szczesio (eds.), Bałkany Zachodnie między przeszłością a przyszłością (pp. 517529). Łódź: Wydawnictwo Uniwersytetu Łódzkiego.

Pieńkowski, J., Żornaczuk, T. (2018). Czwórka Warneńska - nowy format wspótpracy regionalnej. Downloaded from: http://www.pism.pl/publikacje/biuletyn/ nr-77-1650.

Podgórzańska, R. (2006). Integracja regionalna w polskiej polityce zagranicznej na przykładzie Grupy Wyszehradzkiej. In. T. Smoliński (ed.), Modele integracji międzynarodowej. Uniwersalny, kontynentalny, sektorowy a państwo, prawo, idee (pp. 157-186). Szczecin: Wydział Prawa I Administracji Uniwersytetu Szczecińskiego, Wielkopolska Wyższa Szkoła Humanistyczno-Ekonomiczna.

Podgórzańska, R. (2015). Problemy społeczne Bałkanów Zachodnich i ich implikacje dla procesu integracji europejskiej. In. B. Koszel, D. Mierzejewski, Z. Popławski (eds.), Społeczne oblicza Europy XXI wieku (pp. 125-143). Piła: Państwowa Wyższa Szkoła Zawodowa w Pile.

Podgórzańska, R. (2017). Kryzys migracyjny w Unii Europejskiej z perspektywy Bałkanów Zachodnich. Rocznik Integracji Europejskiej, 11, pp. 295-313.

Pytania i odpowiedzi Komisja pod przewodnictwem Junckera. Downloaded from: http://europa.eu/rapid/press-release_MEMO-14-523_pl.htm.

Questions and Answers: The Juncker Commission. Downloaded from: http://europa.eu/rapid/press-release_MEMO-14-523_en.htm).

Sofia Declaration, 17 May 2018. Downloaded from: https://www.consilium.europa. eu/media/34776/sofia-declaration_en.pdf.

Sokołowska, P. (2007). RFN-Unia Europejska i Pakt Stabilności dla Europy Południowo-wschodniej. Rocznik Integracji Europejskiej, 2, pp. 206-237.

Szpala M. (2017). Bałkany Zachodnie coraz dalej od UE. Downloaded from: http:// orka.sejm.gov.pl/WydBAS.nsf/0/E816F0D7A6E9A093C125812200434AD8/\$ file/Infos_229.pdf.

Szpala, M. (2018). Nowe otwarcie w stosunkach Unia Europejska - Bałkany Zachodnie. Downloaded from: https://bit.ly/2rROFXN.

Szymańska, J. (2017). Strategia Unii Europejskiej wobec kryzysu migracyjnego: priorytety, bariery, efekty. Studia BAS, 3, pp. 159-186.

Western Balkans. Downloaded from: https://bit.ly/2Rq9kAW. 
What Is RECOM? Downloaded from: http://recom.link/about-recom/what-isrecom/.

What is the Process of Brdo-Brijuni and what is the Significance for BiH?. Downloaded from: https://bit.ly/2M7asTX.

Zawistowska, R. (2012). Miejsce Bałkanów Zachodnich w polityce Unii Europejskiej. Annales Universitatis Paedagogicae Cracoviensis. Studia Politologica, 7, pp. 200-219.

Żornaczuk, T. (2018). Rozszerzenie UE na Bałkanach: nowa perspektywa wobec starych wyzwań. Downloaded from: http://www.pism.pl/publikacje/biuletyn/ nr-39-1612\#. 